\title{
Quality Characteristics of Soy-akamu Powder Formulated from Sorghum and Sprouted Soybean Flour Blends for Complementary Feeding
}

\author{
Okwunodulu Nwazulu Innocent, Eze Nkechinyere Lucy, Ndife Joel, Ukom Nwankwo Anthony \\ Department of Food Science and Technology, College of Food Sciences and Tourism, Michael Okpara University of Agriculture, Umudike, \\ Nigeria
}

Email address:

nncntokwu@yahoo.com (O. N. Innocent), ezenkechinyere8@gmail.com (E. N. Lucy), jothel2000@gmail.com (N. Joel), tony2008gospel@gmail.com (U. N. Anthony)

\section{To cite this article:}

Okwunodulu Nwazulu Innocent, Eze Nkechinyere Lucy, Ndife Joel, Ukom Nwankwo Anthony. Quality Characteristics of Soy-akamu Powder Formulated from Sorghum and Sprouted Soybean Flour Blends for Complementary Feeding. World Journal of Food Science and Technology. Vol. 3, No. 4, 2019, pp. 48-57. doi: 10.11648/j.wjfst.20190304.12

Received: November 6, 2019; Accepted: November 29, 2019; Published: January 6, 2020

\begin{abstract}
Soy-akamu is nutritionally poor hence the improvement by formulating with sprouted soybean to fortify and restore protein and other nutrients lost during processing to prevent hidden hunger. Sprouted soybean obtained from hand dehulled $12 \mathrm{~h}$ tap water steeped sorted soybean, $72 \mathrm{~h}$ sprouted and $20 \mathrm{~min}$ boiled in $0.05 \%$ sodium bicarbonate solution was milled with $72 \mathrm{~h}$ steeped, drained and washed cleaned sorghum seeds according to 75: 25, 50: 50 and 25: 75 sorghum; sprouted soybean blends. Blended pasts were sieved and dewatered separately with double layered calico cloth to obtain the pastes. Proximate results showed increase in dried matter content (85.94 to $86.68 \%$ ) with increase in soybean paste inclusion, moisture content decreased (14.06 to $13.32 \%)$ protein increased (5.11 to $39.96 \%)$, fat increased (1.51 to $11.21 \%)$, fiber increased $(1.41$ to $4.82 \%$ ), ash increased $(0.46$ to $4.61 \%)$, carbohydrate decreased $(77.44$ to $26.07 \%)$ and energy increased (335.26 to $364.99 \mathrm{Kcal})$. Bulk density increased $(0.33 \%$ to $0.66 \mathrm{~g} / \mathrm{ml})$, viscosity decreased $(117.02$ to $84 \mu$ Pas $)$, swelling power increased (22.83 to 30.04$)$, gelatinization temperature decreased $\left(66.00\right.$ to $\left.45^{\circ} \mathrm{C}\right)$ and gelatinization time increased $(0.35$ to $0.37 \mathrm{sec})$. Gruel from 100\% sorghum scored the highest acceptability. Sprouted soybean blending showed an improvement in the nutrients content of soy-akamu and decrease in acceptability beyond $25 \%$ inclusion.
\end{abstract}

Keywords: Proximate Composition, Functional Properties, Sensory Property, Akamu Paste, Complementary Feeding

\section{Introduction}

Akamu in Igbo or ogi in Youroba is a fermented cereal paste made from maize (Zea mays), sorghum or guinea corn (Sorghum vulgare) [1] or millet (Pennisetum typoideum). The colour of akamu depends on the cereal colour used which may be cream colour from maize, reddish-brown colour from sorghum [2, 1]. Akamu from sorghum is popular in northern Nigeria and most parts of West Africa which porridge or gruel is very smooth in texture and has a sour taste $(\mathrm{pH} 4.8)$ and inhibits growth of some bacteria [3]. Fortification of $o g i$ with legumes, vitamins and minerals alongside improvement on the production techniques which led to the development of soya-ogi, a combination of maize and soybeans have been reported [4].

Increase food use of sorghum in sub-Saharan Africa will alleviate the problem of chronic under-nourishment, as sorghum is readily available in all parts of the countries [2, 1]. However, nutritional problems associated with cereals are their general low protein content and significant less digestible nature when cooked compared to other cooked cereal protein [1]. This could cause protein malnutrition for infants fed exclusively on sorghum based meal. Also, cereals are low in minerals and vitamins which along with protein are essential nutrients needed for the wellbeing and healthy growth and development of infants, children and adults who relish exclusively on akamu. Supplementation of cereals with locally available legumes that is high in protein will increase protein quality and the nutritive values of akamu lost during steeping, milling and sieving processes compared to the use of single cereal $[5,6]$. Also, protein supplementation will 
prevent protein-energy malnutrition in infants weaned exclusively on akamu. As cereals and their products are invariably cooked prior to consumption, these problems are inevitable and require urgent attention.

Several efforts are currently on, in Africa to modify the processing of akamu with a view to enhancing its nutritive value, shelf life and possible therapeutic qualities [2, 7]. One likely method of achieving this is by formulation with soybeans alone [8] or by formulation or may be fortified with vitamins and minerals [4] Also, cereal fermentation was employed to preserve, impart aroma and flavour while producing novelty foods products with improved nutrients for complimentary feeding $[9,10]$.

Soybean oil varies between 13.9 to $23.2 \%$ depending on locality, cultivar and horticultural practices [11] and $40 \%$ higher calorific value than protein and carbohydrates [12]. Soybean is a cheap source of good quality protein with good balance of the essential amino acid and high quality oil [13]. Protein content of soybean contains considerable quantity of lysine $(6.2 \mathrm{~g} / 16 \mathrm{gN})$, but limited by methionine and cystine content $(2.9 \mathrm{~g} / 16 \mathrm{gN})$ [14]. Absence of cholesterol, lactose and presence of essential amino acids makes soybean vital for infant growth and maintenance.

Soybean sprouting is an age long act of improving the nutritive value of legumes, reduction in anti-nutrients and flatulence causing oligosaccharides (stachyose and raffinose), thereby increasing protein digestibility and sensory properties [15]. Also, sprouting increases vitamins, minerals (calcium, copper, manganese, and zinc), nutrient bioavailability and free amino acid. Sprouted soybean had been used to formulate complementary foods [16].

Gruel also known as akamu or ogi when prepared from the paste with hot water after dissolving same with tap water into light thick consistency serves as a major weaning food for the infants in West Africa [17] or by nursing mothers as it encourages breast milk supply, a good vehicle for food nutrients to sick people because it is an energy food rich in carbohydrates with traces of vitamins (Oyelana et al; 2012). it is easily digested and light in the stomach [18]. A blend of sorghum- sprouted soybean will not only boost the nutritive value of akamu as a breakfast meal, weaning food and choice food for the sick [17] but will also boost production and consumption of soybean [19]. This work therefore aimed at improving the protein content of akamu using sprouted soybean paste.

\section{Materials and Methods}

\subsection{Material Procurement}

The sorghum and soybean used for this work were purchased from Urbani, Ibeku ultra modern market Umuahia Abia State, Nigeria.

\subsection{Preparation of Sorghum-soybean Paste (Akamu)}

Sorghum was steeped with clean tap water for $72 \mathrm{~h}$, decanted, washed and wet milled (Power Delux Electric
Blender Model PDB-8231-F) together with the sprouted soybean cotyledons according to formulation (Table 1). Sprouted soybean cotyledons were obtained by sorting/cleaning, steeping (12 hours), sprouting (72h), washing, boiling with $0.05 \%$ sodium bicarbonate for $20 \mathrm{~min}$, and hand dehulled. The paste was then sieved with calico cloth, allowed to sediment, and dewatered with a double layered calico cloth to obtain sorghum-soybean wet paste or akamu (Figure 1).

Steeped sorghum and sprouted dehulled soybean cotyledons were dried in oven at $60^{\circ} \mathrm{C}$ to constant weight, milled and sieved separately after cooling, and blended (Table 1) to obtain flour blends [20].

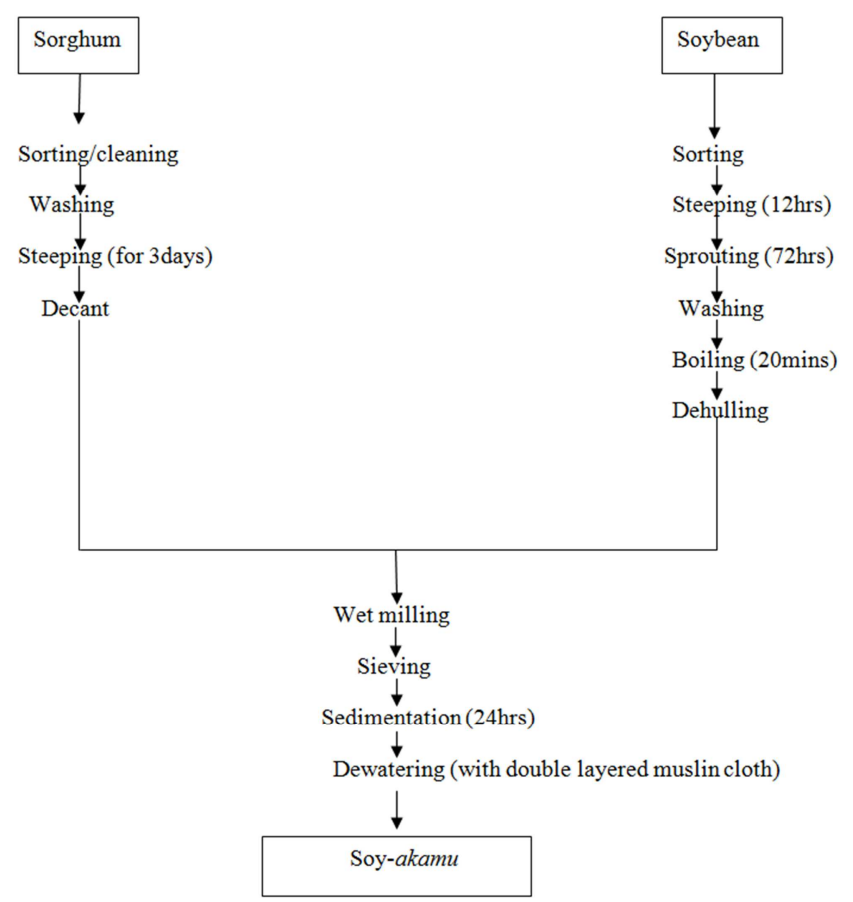

Figure 1. Flow chart for production of sorghum-sprouted soybean akamu paste.

Table 1. Formulation blends for sorghum and sprouted soybean.

\begin{tabular}{lll}
\hline Sample Sorghum (\%) Sprouted soybean & \\
\hline 101 & 100 & 0 \\
104 & 75 & 25 \\
106 & 50 & 50 \\
108 & 25 & 75 \\
\hline
\end{tabular}

\subsection{Proximate Analyses}

\subsubsection{Moisture Content}

Moisture content was determined according to AOAC [21] protocol. Five grams $(5 \mathrm{~g})$ of each sample were placed into a previously washed, dried and weighed moisture cans, dried in the oven at $105^{\circ} \mathrm{C}$ for 3 and placed in a desiccator to cool. Thereafter the process was repeated at a chosen time interval other than $3 \mathrm{hr}$ until a constant weight was obtained. The weight of the moisture lost was calculated as a percentage of weight of sample analyzed as expressed below. 


$$
\% \text { Moisture content }=\frac{W_{2-W_{3}}}{W_{2-W_{1}}} \times \frac{100}{1}
$$

Where $\mathrm{W}_{1}=$ weight of the empty moisture can, $\mathrm{W}_{2}=$ weight of moisture can + sample before drying and $\mathrm{W}_{3}=$ Weight of moisture can + sample dried to constant weight.

\subsubsection{Crude Fiber Content}

Five grams $(5 \mathrm{~g})$ of the sample was boiled for $30 \mathrm{~min}$ with $150 \mathrm{ml}$ of a solution containing $1.25 \mathrm{~g} \mathrm{H}_{2} \mathrm{SO}_{4}$ per $100 \mathrm{ml}$ under reflux. The solution was filtered through a two-fold muslin cloth on a fluted funnel and washed with boiling water until it is no longer acidic. The residue was returned to the flask and boiled for $30 \mathrm{~min}$ with $150 \mathrm{ml}$ of solution containing $1.25 \mathrm{~g}$ of carbonate free $\mathrm{NaOH}$ per $100 \mathrm{ml}$. After washing, the sample was allowed to drain dry before being transferred in a weighed crucible where it was dried in the oven at $105^{\circ} \mathrm{C}$ to a constant weight which was recorded. The sample was finally incinerated in a muffle furnace and the weight of the ash was taken which was used to determine the fiber thus:

$$
\% \text { Crude fiber }=100\left(\mathrm{~W}_{2}-\mathrm{W}_{3}\right)
$$

Where: $\mathrm{W}_{2}=$ Weight of crucible + sample after oven drying and $\mathrm{W}_{3}=$ Weight of crucible + sample after incineration [22].

\subsubsection{Fat Content}

Soxhlet fat extraction method [22] was used. The boiling flask were dried in the oven and cooled in the dessicator. Two gram $(2 \mathrm{~g})$ of each sample was placed in the marked thimbles and weighed. The boiling flask was filled with $300 \mathrm{ml}$ of petroleum ether at $60^{\circ} \mathrm{C}$. The Soxhlet apparatus was assembled and allowed to reflux for 5-6h thereafter the thimble was removed, petroleum ether collected and the flask dried at $105^{\circ} \mathrm{C}$ for 1 hour. It was cooled and weighed. Fat content was calculated as follows:

$$
\% \text { oil }=\mathrm{W}_{2}-\mathrm{W}_{1} / \mathrm{W}_{3} \times 100 / 1
$$

Where: $\mathrm{W}_{1}=$ Weight of empty flask, $\mathrm{W}_{2}=$ Weight of flask + extract and $\mathrm{W}_{3}=$ Weight of sample used.

\subsubsection{Protein}

The Kjeldahl method [23] was used. Two grams (2g) of the samples were mixed with $10 \mathrm{ml}$ of concentrated tetraoxosulphate (VI) acid in a Kjeldahl digestion flask. A tablet of selenium catalysts was added and the mixture was heated inside a fume cupboard. The digest was transferred into a $100 \mathrm{ml}$ volumetric flask, made up with equal volume of $45 \%$ sodium hydroxide $(\mathrm{NaOH})$ solution and poured into a Kjeldahl distilled apparatus. The mixture was distilled and the distillate was collected into a $4 \%$ boric acid solution containing 3 drop of zuazaga indicator (mixture of methyl red and bromacresol green). A total of $15 \mathrm{ml}$ distillate was titrated against $0.02 \mathrm{~N}$ tetraoxosulphate (VI) acid solution until the colour changed from green to a deep red or pink end point. Total nitrogen was calculated and multiplied with the factor 6.25 to get the crude protein content.

$$
\begin{gathered}
\% \text { Crude protein }=\% \mathrm{~N} \times 6,25 \\
\% \mathrm{~N}_{2}=\left(100 \times \mathrm{N} \times 14 \times \mathrm{V}_{\mathrm{F}} / \mathrm{W} \times 1000 \times \mathrm{V}_{\mathrm{A}}\right) \times \mathrm{t} / 1
\end{gathered}
$$

Where: $\mathrm{W}=$ Weight of the sample, $\mathrm{N}=$ Normality of the filtrate, $V_{F}=$ Total volume of the digest $=100 \mathrm{ml}, V_{A}=$ Volume of the digest distilled and $\mathrm{T}=$ Titer volume.

\subsubsection{Carbohydrate}

Carbohydrate content of the paste samples was calculated by difference [23] thus:

$$
\% \mathrm{CHO}=100 \%-\%(\mathrm{a}+\mathrm{b}+\mathrm{c}+\mathrm{d}+\mathrm{e})
$$

Where: $\mathrm{CHO}=$ carbohydrate, $\mathrm{a}=$ protein, $\mathrm{b}=$ fat, $\mathrm{c}=$ crude fiber, $\mathrm{d}=$ ash and $\mathrm{c}=$ moisture.

\subsubsection{Ash Content}

Ash content was determined by furnace incineration gravimetric method [22]. Five grams $(5 \mathrm{~g})$ of the sample were placed into washed, oven dried and weighed porcelain crucible. The sample was incinerated at $550^{\circ} \mathrm{C}$ for $3 \mathrm{~h}$ to grayish ash in a muffle furnace, cooled in a desiccator and weighed. Weight of the ash obtained was determined $b / y$ difference and expressed as a percentage of the weight of the samples incinerated as shown:

$$
\% \mathrm{ash}=100 \times\left[\mathrm{W}_{3}-\mathrm{W}_{1}\right] /\left[\mathrm{W}_{2}-\mathrm{W}_{1}\right]
$$

Where:

$\mathrm{W}_{1}=$ Weight of empty crucible, $\mathrm{W}_{2}=$ weight of crucible + food before drying and/or ashing and $\mathrm{W}_{3}=$ Weight of crucible + ash.

\subsubsection{Energy Values}

Proximate values of crude fat, protein, fiber and carbohydrate (Table 1) were used for the calculation of energy levels of the samples using Atwater factor [24].

\subsection{Functional Properties}

Functional properties of sorghum and soybean flour blends were determined.

\subsubsection{Bulk Density}

Ten grams $(10 \mathrm{~g})$ of the sample were measured into $100 \mathrm{ml}$ graduated measuring cylinder and tapped on repeatedly on a pad placed on a laboratory bench until no further reduction in volume occurred [22]. Bulk density was determined as the ratio of the weight of the sample to its volume as shown below:

\section{Bulk density $=\mathrm{W} / \mathrm{V}\left(\mathrm{g} / \mathrm{dm}^{3}\right)$}

Where: $\mathrm{W}=$ weight of sample in grams and $\mathrm{V}=$ volume of sample $\left(\mathrm{dm}^{3}\right)$

\subsubsection{Viscosity}

Ten grams $(10 \mathrm{~g})$ flour was suspended in $100 \mathrm{ml}$ distilled water and mechanically stirred for $2 \mathrm{~h}$ at room temperature and the viscosity was measured using bench rotary viscometer, NDS-55 Surgifriend Medical England [22]. 


\subsubsection{Gelatinization Temperature}

Ten grams $(10 \mathrm{~g})$ of the flour sample were suspended in $100 \mathrm{ml}$ of water in a test tube. The aqueous suspension was heated in a boiling water bath with continuous stirring and the temperature at which gelatinization was visually noticed was recorded as the gelatinization temperature [22].

\subsubsection{Swelling Power Index}

Swelling power is a measure of the hydration capacity of starch expressed as the weight of centrifuged swollen granules, divided by the weight of the original dry starch used to make the paste. Two grams $(2 \mathrm{~g})$ of the flour samples were suspended in $10 \mathrm{ml}$ of water and incubated in a thermostatically controlled water bath at $95^{\circ} \mathrm{C}$ in a tarred screw cap tube of $15 \mathrm{ml}$. The suspension was stirred intermittently for $30 \mathrm{~min}$ period to keep the starch granules suspended. The samples were then rapidly cool to $20^{\circ} \mathrm{C}$ with cool water and centrifuged/ at $2200 \times \mathrm{g}$ for 15 minutes to separate the jelly and the supernatant [25].

\section{Swelling power $=\mathrm{W}_{2} \times 100 / \mathrm{Wdm}(100$-solubility $)$}

Where: $\mathrm{W}_{2}=\mathrm{W} /$ eight of centrifuged swollen granules and $\mathrm{Wdm}=$ weight of original dry sample

\subsubsection{Gelatinization Capacity}

The method of Onwuka [22] was used. Five grams (5g) of each flour sample was dissolved in $100 \mathrm{ml}$ of distilled water in a $500 \mathrm{ml}$ beaker to obtain $5 \%$ sample suspension. Two $(2 \mathrm{ml})$ of the sample was dissolved in $5 \mathrm{ml}$ distilled water in attest tube, heated for $1 \mathrm{hr}$ in a boiling water bath and cooled rapidly under running cool tap water. The test tube was cool further for $2 \mathrm{~h}$ at $4^{\circ} \mathrm{Cand}$ inverted. The gelation capacity is the least gelation concentration determined when the sample from inverted test tube will not fall $\mathrm{o} / \mathrm{r}$ slip.

\section{Sensory Evaluation}

Twenty (20) semi trained panelists randomly selected from the students of Michael Okpara University of Agriculture, Umudike within the age bracket of 18 to $30 \mathrm{yr}$ who are familiar with the gruel were used. The coded/ samples were presented to each panelist separately in same types of saucers along with bottled water/under bright illumination. They were to taste the sample one after the other, rinse their mouths after e/ach tasting and score the samples using 9point Hedonic scale [27] where 9 represents dislike extremely, 1 dislike extremely, and 5 neither like nor dislike. Appearance, flavour, taste, texture and general acceptability were evaluated [26].

\section{Statistical Analyses}

Data obtained from the analyses were subjected to analysis of variance (ANOVA) using SPSS software package version 20. Means were separated using Duncan Multiple Range test to determine the significant difference at $5 \%$ probability.

\section{Results and Discussion}

\subsection{Proximate Composition}

Table 1 summarized the proximate composition results of the sorghum - sprouted soybean paste blends.

\subsubsection{Dry Matter}

Percentage dry matter (DM) content of the paste samples ranged from $85.78 \%$ in sample $104(100 \%$ sorghum) to $86.68 \%$ in 108 (25\% sorghum: $75 \%$ sprouted soybean). Significant difference $(\mathrm{p}<0.05)$ between all the dry matter content of the samples prefigured significant variations in dry matter contributions of various blends in the formulations. Lower dry matter content of sample 104 (100\% sorghum) than the rest samples indicated that sorghum had more moisture than the rest blends most especially $25 \%$ sorghum and $75 \%$ sprouted soybean probably due to higher proportion of sprouted soybean. Soybean is a legume which protein digestibility and free amino acids increases with sprouting [15, 28]. Proteins bound and hold water [29] which may have contributed in lowering sample moisture content as substantiated in the table which showed dry matter increase with increase in soybean inclusion.

Table 2. Proximate Composition of ogi Paste from Sorghum and Sprouted soybean Blends (\%).

\begin{tabular}{|c|c|c|c|c|c|c|c|}
\hline Sps DM/ & MC & $\mathbf{C P}$ & $\mathbf{E E}$ & $\mathbf{C F}$ & ASH & CHO & EV (Kcal) \\
\hline $10185.94 /{ }^{\mathrm{f}} \pm 0.03 /$ & $14.06^{\mathrm{b}} \pm 0.03$ & $5.11^{\mathrm{g}} \pm 0.02$ & $1.51^{\mathrm{g}} \pm 0.00$ & $1.41^{\mathrm{g}} \pm 0.01$ & $0.46^{\mathrm{d}} \pm 0.00$ & $77.44^{\mathrm{b}} \pm 0.00$ & $335.26^{\mathrm{d}} \pm 0.06$ \\
\hline $10 / 485.78^{\mathrm{g}} \pm 0.01 /$ & $14.22^{\mathrm{a}} \pm 0.01$ & $17.20^{\mathrm{e}} \pm 0.00$ & $6.55^{\mathrm{e}} \pm 0.00$ & $2.81^{\mathrm{e}} \pm 0.01$ & $1.77^{\mathrm{c}} \pm 0.02$ & $57.43^{\mathrm{d}} \pm 0.00$ & $348.93^{\mathrm{b}} \pm 0.04$ \\
\hline $10 / 685.84^{\mathrm{g}} \pm 0.01 /$ & $14.16^{\mathrm{a}} \pm 0.01$ & $25.68^{c} \pm 0.03$ & $9.85^{\mathrm{c}} \pm 0.00$ & $3.94^{\mathrm{c}} \pm 0.01$ & $2.85^{\mathrm{b}} \pm 0.01$ & $43.52^{\mathrm{f}} \pm 0.01$ & $364.99^{\mathrm{a}} \pm 0.01$ \\
\hline $10 / 886.68^{e^{e}} \pm 0.03 /$ & $13.32^{\mathrm{e}} \pm 0.03$ & $39.96^{\mathrm{a}} \pm 0.01$ & $11.21^{\mathrm{a}} \pm 0.02$ & $4.82^{\mathrm{a}} \pm 0.01$ & $4.61^{\mathrm{a}} \pm 0.01$ & $26.07^{\mathrm{h}} \pm 0.00$ & $335.70^{c} \pm 0.14$ \\
\hline
\end{tabular}

$\mathrm{Va} /$ lues are mean triplicate determinations \pm standard deviation Values with the same superscript within the same column are not significantly different $(\mathrm{p}</ 0.05)$ while those with different superscript are significantly different. Sps $=$ samples, DM=Dry matter, $\mathrm{MC}=\mathrm{Moisture}$ contents, $\mathrm{CP}=\mathrm{Crude}$ protein, $\mathrm{EE}=/$ Ether extract, $\mathrm{CF}=$ Crude fiber, $\mathrm{EV}=$ Energy value, $\mathrm{CHO}=$ Carbohydrate. $101=100 \%$ sorghum $104=75 \%$ sorghum and $25 \%$ sprouted soybean, $106=50 \%$ sorgh/um and $50 \%$ sprouted soybean and $108=25 \%$ sorghum and $75 \%$ sprouted soybean.

\subsubsection{Moisture Content}

Increase in moisture contents (MC) of the paste samples from $13.32 \%$ in sample 108 (25\% sorghum: $75 \%$ sprouted soybean) to $14.22 \%$ in sample 104 (75\% sorghum: $25 \%$ sprouted soybean) validated the inverse relationship of DM with moisture earlier reported. The difference could be traced in part to the variations in proportions of sorghum and sprouted soybean in the formulation as evident in moisture content decrease with increase in sprouted soybean and increase with increase in sorghum (Table 1) in all the samples. Moisture content decreased due to sprouted soybean 
may be attributed to soybean protein which binds and holds water (Igyor et al., 2011). Variations in amylase and amylopectin proportions of sorghum may also contribute to the difference. Amylase is more soluble in water than amylopectin [30]. Moisture content similarities between samples 104 (75\% sorghum: 25\% sprouted soybean) and106 (50\% sorghum and $50 \%$ sprouted soybean) may mean that their blend variations did not have any significant $(p<0.05)$ different impart. Despite high MC of akamu wet paste still keep for some times on the shelf which can be attributed to fermentation that took place during $72 \mathrm{~h}$ steeping thereby reduced microbial substrates.

\subsubsection{Crude Protein Content}

Protein is an energy substrate which is crucial for regulation and maintenance of infants' and young children's body [31]. Crude protein content obtained in this study ranged from $5.11 \%$ in sample 101 (100\% sorghum) to $39.96 \%$ in sample 108 (25\% sorghum: $75 \%$ soybean). And will meet the recommended protein content for complementary foods of $13 \mathrm{~g} / \mathrm{d}$ for infants aged from 0 to 2 years [32] by consuming $254 \mathrm{~g} / \mathrm{d}$ of paste from $100 \%$ sorghum while that from $25 \%$ sorghum: $75 \%$ soybean is an excellent protein source as it could meet the protein RDI per serving [33]. This is possible considering infant stomach capacity of $200 \mathrm{ml}$ [34]. Besides, both gruel samples are liable to prevent marasmus and kwashiorkor as well. Therefore, significant increase in protein content recorded in the paste could be traced to sp/routed soybean [35] which contained higher proteins than sorghum (cereals). Increase in protein content of the paste with increase in soybean substitution was validated by the significant $(\mathrm{p}<0.05)$ difference between samples 101 (100\% sorghum) and 108 ( $25 \%$ sorghum: $75 \%$ soybean).

\subsubsection{Crude Fat Content}

Crude fat content of the samples increased with increase in soybean inclusion in the blends as shown in the significant higher fat content in sample 108 (25\% sorghum: $75 \%$ soybean) than sample 101 (100\% sorghum). This could be attributed to soybean which is an oil rich legume as can be visualized in the increasing fat content with increase in sprouted soybean inclusion in the table. Also significant $(p<0.05)$ fat content variation between all the samples substantiated significant $(\mathrm{p}<0.05)$ difference in fat content contributions of various soybean proportions in the blends. Besides, all the pudding samples from both varieties with same formulations were significantly difference $(p<0.05)$ from each other. Fat contribution by the sprouted soybean harmonized with $\mathrm{FAO} / \mathrm{WHO}$ recommendations of vegetable oil inclusion in infant and children foods [36] to increase the energy density and transport vehicle for fat soluble vitamins. Soybean contains considerable amount of polyunsaturated oil, omega-3 fatty acid and linolenic fatty acids which are good heart health nutrients for infants, children and adults [37]. Fat is a good source of energy, fat soluble vitamins and helps to increase food palatability as it absorbs and retains flavours [38].

\subsubsection{Crude Fiber}

Crude fiber con/tents of the paste increased from $1.41 \%$ in sample $101(100 \%$ sorghum) to $4.82 \%$ in sample 108 (25\%/sorghum: $75 \%$ soybean) which implied that sprouted soybean was responsible for crude fiber increase/e as shown in the table. Also, DM increase with sprouted soybean inclusion earlier reported may have contributed too. Significant different $(p<0.05)$ between all the samples may imply significant $(p<0.05)$ variations in fiber contributions of various blends.

Consumption of 1.04 to $3.55 \mathrm{~g} / \mathrm{d}$ of gruel samples will meet fiber RDI of $5 \mathrm{~g} / \mathrm{d}$ [39] for infants aged between $6 \mathrm{~m}$ to one year which made them a good fiber source [40]. Crude fiber is a carbohydrate subtype consisting of soluble and insoluble portions which increases roughages content of diet responsible, normalizing infant's bowel movement, prevents constipation, aids easier evacuation of stool and helps control blood pressure [39]. Dietary fiber helps in prevention of several diseases such as cancer, constipation, diabetes an/d intestinal diverticulitis [41, 42].

\subsubsection{Ash Content}

Ash content of the paste/ samples which increased from $0.46 \%$ in sample 101 (100\% sorghum) to $4.61 \%$ in sample 108 (25\% sorghum: $75 \%$ soybean) implicated sprouted soybean inclusion levels in the formulation. Ash increase/ with sprouted soybean increase is evident in the table. Significant different $(\mathrm{p}<0.05)$ between all the samples may imply significant $(\mathrm{p}<0.05)$ ash content increase by each soybean inclusion level. This may as well confirm higher ash content in sprouted soybean than sorghum. As ash is an index of mineral content of meal, sprouted soybean will go a long way in enhancing the mineral content of akamu successfully to meet the mineral need of the weaning infants.

\subsubsection{Carbohydrate Content}

Carbohydrate content of the paste which increased from $26.07 \%$ in sample 108 (25\% sorghum: $75 \%$ soybean) to $77.44 \%$ in sample 101 (100\% sorghum) implies that sorghum had more carbohydrate than soybean. Carbohydrate content of the paste decreased with increase in sprouted soybean inclusion in the blends as recognized in the table. Significant $(\mathrm{p}<0.05)$ different between all the paste samples again may signify significant variations in carbohydrate contributions of various blends. Soybean contains low carbohydrate (sucrose, starchyose and raffinose). Steeping and sprouting reduce starchyose and raffinose while sucrose is hydrolyzed into simple sugar [43]. Carbohydrates provides energy needed to fuel children's metabolism, supports growth, keeps their brain and nervous systems working and maintains overall health [44]. All the sprouted soybean blended pastes were good sources of carbohydrate despite their lower carbohydrate contents compared to $100 \%$ sorghum. Consumption of 2.30 to $3.64 \mathrm{~g} / \mathrm{d}$ of paste from sprouted soybean blended paste and 0.78 to $1.23 \mathrm{~g} / \mathrm{d}$ of paste from $100 \%$ sorghum will meet the recommended daily carbohydrate intake (RDI) of 60 to $95 \mathrm{~g} / \mathrm{d}$ for infants aged between 6 to 12 
months [32].

\subsubsection{Energy Values}

Least energy value $(335.26 \mathrm{Kcal})$ of sample $101(100 \%$ sorghum) could be traced to least protein content due to absence of sprouted soybean. Sample 106 (50\% sorghum: $50 \%$ sprouted soybean) had the highest energy value (364.9) $9 \mathrm{~K}$ ) than the rest samples probably due to higher contributions of all its energy substrates which ranked second except in carbohydrate. Protein, fat and crude fiber were enhanced by sprouted soybean (Table 1). Significant $(p<0.05)$ energy difference between all the samples still point to the influence of sprouted soybean in the formulations.

\subsection{Functional Properties}

Results of functional properties of flour blends of sorghum and sprouted soybeans were shown in Table 2.

\subsubsection{Bulk Density}

Bulk density ranged from 0.33 in sample $101(100 \%$ sorghum) to 0.66 in sample $108(25 \%$ sorghum: $75 \%$ sprouted soybean) with significant $(\mathrm{p}<0.05)$ difference between all the samples which may be attributed to significant $(\mathrm{p}<0.05)$ variations in bulk density contributions of the various blends. Highest bulk density value of sample 108 (25\% sorghum: $75 \%$ sprouted soybean) than the least value of sample 101 (100\% sorghum) may mean that sprouted soybean paste contributed more bulk density than sorghum. This is substantiated by the increasing bulk density values of the samples with increasing substitution of sprouted soybean paste in all the samples. Bulk density depends on the intensity of attractive inter-particle forces, particle sizes as well as the number of contact points [45]. Hydrolysis of soybean due to sprouting which results in smaller particle sizes with larger surface areas may have favoured increase in bulk density of sprouted soybean.

Table 3. Functional Properties of Sorghum and Sprouted Soybean flour Blends.

\begin{tabular}{llllll}
\hline Products & Bulk density $(\mathbf{g} / \mathbf{m l})$ & Viscosity $(\boldsymbol{\mu} /$ Pas) & Swelling power & G-temperature $\left({ }^{\circ} \mathbf{C}\right)$ & G-time $($ seconds) \\
\hline 101 & $0.33^{\mathrm{h}} \pm 0.00$ & $117.02^{\mathrm{a}} \pm 0.01$ & $22.83^{\mathrm{a}} \pm 0.03$ & $66.00^{\mathrm{b}} \pm 0.00$ & $0.35^{\mathrm{e}} \pm 0.00$ \\
104 & $0.50^{\mathrm{g}} \pm 0.00$ & $109.04^{\mathrm{b}} \pm 0.02$ & $24.72^{\mathrm{d}} \pm 0.01$ & $65.50^{\mathrm{b}} \pm 0.50$ & $0.36^{\mathrm{c}} \pm 0.01$ \\
106 & $0.61^{\mathrm{f}} \pm 0.00$ & $102.02^{\mathrm{f}} 0.02$ & $27.04^{\mathrm{b}} \pm 0.01$ & $49.00^{\mathrm{f}} \pm 0.00$ & $0.50^{\mathrm{a}} \pm 0.01$ \\
108 & $0.66^{\mathrm{e}} \pm 0.00$ & $84.09^{\mathrm{g}} \pm 0.01$ & $30.04^{\mathrm{a}} \pm 0.01$ & $45.00^{\mathrm{c}} \pm 0.00$ & $0.57^{\mathrm{d}} \pm 0.01$ \\
\hline
\end{tabular}

Values are mean duplicate determinations \pm standard deviation. Values with same superscript within same column are not significantly different (p0.05). Values with different superscript within same column are significantly different. 101=100\% sorghum, 104=75\% sorghum: $25 \%$ sprouted soybean, $106=50 \%$ sorghum: $50 \%$ sprouted soybean and $108=25 \%$ sorghum: $75 \%$ sprouted soybean.

\subsubsection{Viscosity}

Viscosity of the flour blends was highest (117) in sample 101 (100\% sorghum) and least (84) in 108 (25\% sorghum: $75 \%$ sprouted soybean) with significant $(\mathrm{P}<0.05)$ different between all the samples. The difference between the two viscosity values could be attributed to sprouted soybean inclusion as shown in Table 3 where viscosity decreased with increase inclusion of sprouted soybean flour. Sprouting thins down viscosity as most of the carbohydrates were hydrolyzed during sprouting unlike $100 \%$ sorghum flour Significant $(p<0.05)$ variations between samples may mean significant $(p<0.05)$ variations in viscosity contributions by the blends. Viscosity is an indication of viscous gel after cooling and resistance to shear forces during shearing [46].

\subsubsection{Swelling Power}

Swelling power of the dried paste samples was highest (30.04) in sample 108 (25\% sorghum: $75 \%$ sprouted soybean) and least (22.83) in sample 101 (100\% sorghum) with significant $(\mathrm{p}<0.05)$ difference between all the samples. The difference could be attributed in part to the type of sorghum starch granules as well as inclusion of sprouted soybean which increased with increase in swelling power. Swelling power had been reported as indication of water holding capacity of starch and is generally used to differentiate between various types of starches [47, 48]. Water binding capacity in commercial starches stabilizes the quality and texture of some food products against syneresis during processing, storage and freezing. Besides, swelling power is related to protein and starch contents [49]. Therefore, soybean paste inclusion may likely contribute to the stability of the akamu paste. Protein hydrolyses during sprouting of soybean may have enhanced the swelling power of sample 108 (25\% sorghum: $75 \%$ sprouted soybean) as high product protein content will embed the starch granules within its stiff matrix and gradually reduces their access to water thereby restrict the swelling power [50]. Higher swelling power of sprouted soybean suggested higher amylopectin content which is primarily responsible for granule swelling. Low amylase content is associated with high swelling power due to low reinforcement in the internal network by amylase molecules [51]. Higher swelling power of sprouted soybean used implies higher digestibility of the gruel made from their blends as amylase is more resistant to digestion due to its highly packed helical structure [30].

\subsubsection{Gelatinization Temperature}

Gelatinization temperature of the samples increased from $49^{\circ} \mathrm{C}$ in sample $106(50 \%$ sorghum and $50 \%$ sprouted soybean) to $66 \%$ in sample 101 (100\% sorghum). Significant $(p<0.05)$ difference between all the samples implies that akamu paste formulated from 50\% sorghum and 50\% sprouted soybean will form gel at a significantly $(\mathrm{p}<0.05)$ lower temperature than the rest sample blends. This may be attributed to variety, particle size of starch granules, and the proportion of amylose and amylopectin content of sorghumsprouted soybean blends. Besides, Lower gelatinization temperature of sample 106 (50\% sorghum and 50\% sprouted 
soybean) could be due to sprouted soybean paste inclusion. Sprouting may have predigested the soybean paste [37] thereby lowered their gelatinization temperature as could be seen in the decreasing trend of gelatinization temperature with increasing sprouted soybean paste substitution in Table 3. This may mean that sprouted soybean paste used in the formulation is compatible and complimentary to the akamu.

\subsubsection{Gelatinization Time}

Samples gelatinization time increased from $0.35 \mathrm{sec}$ in sample 101 (100\% sorghum) to $0.57 \mathrm{sec}$ in sample $108(25 \%$ sorghum: $75 \%$ sprouted soybean) with similarity between only samples 101 (100\% sorghum) and 104 (75\% sorghum: $25 \%$ sprouted soybean). The difference may be attributed to earlier report of higher amylopctin composition of sprouted soybean than sorghum starch which is larger in size and requires more time to gelatinize unlike in amylase. Therefore, inclusion of sprouted soybean increased the gelatinization time as evident in Table 3 where the gelatinization time increased with increasing substitution of sprouted soybean in the formulation. Similarity in gelatinization time between samples 101 (100\% sorghum) and 104 (75\% sorghum: 25\% sprouted soybean) could be due to minimal (25\%) substitution of sorghum with sprouted soybean which made no significant $(\mathrm{p}<0.05)$ difference between them. Conversely, significant $(\mathrm{p}<0.05)$ difference between samples $106(50 \%$ sorghum and 50\% sprouted soybean) and 108 (25\% sorghum: $75 \%$ sprouted soybean) could be due to higher substitution values ( $50 \%$ and $75 \%$ respectively) of sorghum with sprouted soybean.

\subsection{Sensory Attributes}

Sensory attributes of gruel prepared from sorghumsprouted soybean formulated paste samples are presented in Table 4

\subsubsection{Appearance}

Appearance scores of the gruel samples which ranged from 5.84 in sample 104 (75\% sorghum: $25 \%$ sprouted soybean) to 7.30 in sample 101 (100\% sorghum) may be attributed to inclusion of sprouted soybean which decreased appearance with increasing inclusion. Appearance score levels showed significant $(\mathrm{p}<0.05)$ difference between samples $101(100 \%$ sorghum) and the rest samples which similarities probably could be due to insignificant $(0>0.05)$ effects on appearance by sprouted soybean inclusion levels, Appearance is an important sensory feature of any food product which decides acceptability as consumers eat with their eyes and use what they observed to predict quality [31].

Table 4. Sensory Attribute of Gruel Prepared from Sorghum and Sprouted Soybean Blends.

\begin{tabular}{|c|c|c|c|c|c|}
\hline Product & Appearance & Taste & Thickness & Smoothness & G. acceptability \\
\hline 101 & $7.30^{\mathrm{a}} \pm 1.34$ & $6.20^{\mathrm{bc}} \pm 1.10$ & $8.25^{\mathrm{a}} \pm 0.72$ & $6.65^{\mathrm{a}} \pm 0.67$ & $7.10^{\mathrm{a}} \pm 0.85$ \\
\hline 104 & $5.85^{\mathrm{b}} \pm 1.87$ & $4.60^{\mathrm{de}} \pm 1.87$ & $5.25^{\mathrm{cd}} \pm 2.02$ & $6.00^{\mathrm{a}} \pm 2.22$ & $5.25^{\mathrm{a}} \pm 2.2 .9$ \\
\hline 106 & $6.00^{\mathrm{ab}} \pm 2.07$ & $2.90^{\mathrm{f}} \pm 1.71$ & $4.80^{\mathrm{d}} \pm 2.04$ & $6.25^{\mathrm{a}} \pm 1.77$ & $4.30^{\mathrm{b}} \pm 2.00$ \\
\hline 108 & $6.00^{\mathrm{ab}} \pm 1.95$ & $4.45^{\mathrm{e}} \pm 2.01$ & $4.75^{\mathrm{d}} \pm 2.40$ & $6.75^{\mathrm{a}} \pm 1.80$ & $4.42^{\mathrm{b}} \pm 2.04$ \\
\hline
\end{tabular}

Values are the means of the triplicate determinations \pm standard deviation, Values in same column with same superscripts are not significantly different (p0.05) and means with different superscripts are significantly $(\mathrm{p}<0.05)$ different. Sample codes; $101=100 \%$ sorghum, 104=75\% sorghum and $25 \%$ sprouted soybean, $106=50 \%$ sorghum: $50 \%$ sprouted soybean and $108=25 \%$ sorghum: $75 \%$ sprouted soybean.

\subsubsection{Taste}

Higher taste score (6.20) of gruel sample $101(100 \%$ sorghum) than 2.90 from sample 106 (50\% sorghum: 50\% sprouted soybean) could be due to familiarity of the panelists with gruel from sorghum starch. Significant $(p<0.05)$ different between all the samples may prefigure significant $(p<0.05)$ variations in taste contributions of various levels of formulations as observed in the decreasing taste scores of the gruel samples with sprouted soybean inclusion levels compared to that of $100 \%$ sorghum gruel. Therefore, sprouted soybean inclusion should be with caution (less than $25 \%$ ) to avoid total loss of acceptability. Probably that is why sample 106 (50\% sorghum: 50\% sprouted soybean) had the least taste score. Higher (6.20) taste score of $100 \%$ sorghum gruel may mean that taste attributes which include sweet, sour, bitter, salty, umami and other basic taste [52] were not influenced unlike in those formulated with sprouted soybean.

\subsubsection{Thickness}

Higher thickness value (8.25) of sample $101 \quad(100 \%$ sorghum) than the least value (4.75) of sample $108(25 \%$ sorghum: $75 \%$ sprouted soybean) is traceable to sprouted soybean inclusion levels. Sprouting thins down (Iwe, 2010) the thickness of the gruel and hydrolyzes the native starch to simple sugar thereby reducing their thickening power. This is evident in the decreasing trend of the gruel thickness with increasing sprouted soybean inclusion in Table 4. Similarity between samples 106 (50\% sorghum: 50\% sprouted soybean) and 108 (25\% sorghum: $75 \%$ sprouted soybean) could stem from the difference $(25 \%)$ in their sprouted soybean inclusion which never had any significant $(p<0.05)$ thickness effect.

\subsubsection{Smoothness}

There were no significant $(p>0.05)$ difference between the smoothness of all the gruel samples. The similarities could be attributed to varieties of sorghum and soybean (granule sizes), steeping and sprouting which probably never had significant $(p<0.05)$ variations in the gruel smoothness. While steeping softens the starch, sprouting hydrolyzed the starch to simple sugars, both of which may have enhanced gruel smoothness equally. The smoothness scores increased from 6.00 in sample 104 (75\% sorghum: $25 \%$ sprouted soybean) to 6.75 in sample 108 (25\% sorghum: $75 \%$ sprouted soybean. The variation may be likened to the amount of sprouted soybean in the both blends. Sample 108 (25\% sorghum: 75\% sprouted 
soybean) had more of sprouted soybean (50\%) inclusion than 104 (75\% sorghum: $25 \%$ sprouted soybean) which had more sorghum $(50 \%)$. The difference may have been responsible for their significant $(\mathrm{p}<0.05)$ difference. Thickness is an index is grittiness which in turn decides ease of swallowing. All the gruel samples are generally smooth which signified absence of swallowing problems.

\subsubsection{General Acceptability}

Sample 101 (100\% sorghum) scored highest (7.10) by the panelists probably because they were used to gruel prepare from $100 \%$ sorghum. The least accepted was sample $106(50 \%$ sorghum: $50 \%$ sprouted soybean) may be due to level of sprouted soybean inclusion (above 25\%). Similarities of samples 104 (75\% sorghum and $25 \%$ sprouted soybean) to 101 (100\% sorghum), and 108 (25\% sorghum: $75 \%$ sprouted soybean0 to 106 (50\% sorghum: $50 \%$ sprouted soybean) implied that general acceptability of the gruel decreased with increase in sprouted soybean inclusion most especially beyond $25 \%$. Also, it may mean that variations in their formulations had no significant $(p<0.05)$ difference contributions in general acceptability. General acceptability depends on combination of all other sensory parameters and any product with maximum acceptability levels in most of the attributes will have maximum overall acceptability [53]. Maximum acceptability score (7.10) was justified with maximum scores in all the attributes evaluated. Following suit is gruel from sample 104 with maximum scores in taste and thickness, second in appearance and third in smoothness.

\section{Conclusions}

Supplementation of sorghum with sprouted soybean in akamu preparation is compatible as different proportions of the formulations contributed significant increase in protein, fat, ash, crude fiber and energy, and lowered carbohydrate contents. Some of the functional properties of the supplemented gruel samples like bulk density, swelling power and gelatinization time were also increased while viscosity and gelatinization temperature were decreased. Sensory evaluation revealed only increase in smoothness while appearance, taste, thickness and general acceptability were reduced most especially at inclusion level of sprouted soybean above $25 \%$. Therefore, supplementation should be with caution, not more than $25 \%$, to avoid loss of acceptability and thickness. Soy-akamu is therefore a good candidate for complementary feeding, breakfast meal for elderly people and those recovering from sickness to combat hidden hunger and protein energy malnutrition (PEM) problems among children of developing countries.

\section{Acknowledgements}

We are grateful to the Department of Food Science and Technology, Michael Okpara Universsity of Agriculture Umudike Abia State Nigeria for their supply of reagents and laboratory space.

\section{References}

[1] Omole J. O, Ighodaro O. M and Durosinolorun O. (2017). Fortification of Ogi with whey increases Essential Amino Acid content of fortified product. International scholarly Research Notices, volume 2017, Article ID 7450845.

[2] Ogodo A. C, Ugbogu O, Ekeleme U (2015). Bacteriological Quality of commercially prepared fermented ogi (Akamu) sold in some parts of South Eastern Nigeria, International Journal of Biological, Biomolecular, Agricultural, Food and Biotechnological Engineering: 9,: 6.

[3] Ladunni E; Aworh, O. C; Oyeyinka S. A and Oyeyinka A. T (2013). Effects of drying method on selected properties of ogi (gruel0 prepared from sorghum (sorghum valgare) millet (pennisetum glaucum) and maize9zea mays). Journal of food processing and technology. ISSN: 2157-7110.

[4] Jude-Ojei B. S, Lola, A, Ajayi, O and Iiemobayo S (2017). Functional and pasting properties of maize "ogi" supplemented with fermented moringa seeds. Journal of food processing and technology. 8: 5.

[5] Okafor U. I, Omemu A. M, Obadina A. O, Bankole M. O, Adeyeye S. A (2018). Nutritional composition and antinutritional properties of maize ogi cofermented with pigeon pea. Food Science and Nutrition, 6, 2.

[6] Achi, O, K. (2005) The potential of upgrading traditional fermented foods through African Journal of biotechnology. 4 (22); 375-380.

[7] Ogbona C. N, Nozaki, K and Yajima, H (2013), Antimicrobial activity of xylopia aethiopica, Aframomum Melegueta and piper guinenses ethanolic extracts and the potential of using xylopia aethiopica to preserve fresh orange juice, African Journal of Biotechnology, 12, 6.

[8] Adeleke, A. O. and Oyewole, O. B. (2010). Production of ogi from germinated sorghum supplemented with soybeans. African Journal Biotechnology, 9 (42), 7114-7121.

[9] Ijabadeniyi, A. O. (2004). Microorganisms associated with ogi, traditionally produced from three varieties of maize supplemented with soybeans. Journal of Food Science and Technology, 17, 139-148.

[10] Omemu, A. M., Oyewole, O. B. and Bankola, M. O. (2007). Significant of yeasts in the fermentation of maize for ogi production. Food Microbiology, 24, 571-576.

[11] Iwe, M. O. (2003). The Science and Technology of Soybean. Published by Rojoint Communication Services Ltd., 27-262.

[12] United Soybean Board (USB) (2010). Nutritional Composition. http:/www.soy.connection.com/healthnutrtion/technical_info/nu tritional_composition.php.

[13] Amusat, A. S. and Ademola, A. O. (2013). Utilization of soybean in Oniyo community of Oyo state, Nigeria. Global Journal Science Frontier Research, 13 (7) 1.

[14] Hany, A. E (2011). Soybean and Nutrition. Janeza Trdine 9, 51000 Rijeka, Croatia.

[15] Iwe, M. O. (2003). The Science and Technology of Soy bean: Chemistry, Nutrition, Processing and utilization. 1st edition. Rojoint communication services. Enugu. 
[16] Okwunodulu1, I. N. Uluocha, D. M. and Okwunodulu, F. U. (2019). Influence of plantain and sprouted soybean pastes on the nutrient and proximate composition of two species of cocoyam puddings as a complementary food. Sustainable Food Production. ISSN: 2624-876X 5, 24-37.

[17] Oyewole, O. B. (1997). Lactic fermented foods in Africa and their benefits. Food Control, 8, 289-297.

[18] Oyelana O. A and Coker, A. A (2012). Microbial contamination at Different stages of production of Ogi in Mowe: A Rural community southwest, Nigeria. Bacteriological Journal 2: 1-11.

[19] Alabi, M. O. and Anuonye, J. C. (2001). Creating awareness on utilization of soybean baked product and catering industry. A preliminary study of soil cake, physical properties and acceptability. Polo Math Journal, 2 (1), 8-12.

[20] Akambi, B. O., Olubunmi, O., Agarry, O. O. and Garba, S. A. (2010). Quality assessment of selected cereal- soybean mixtures in "ogi" production New York Science Journal, 3 (10), 17-26.

[21] AOAC (2000). Association of Official Analytical Chemists, Official methods of analysis 18th edition Washington DC. USA.

[22] Onwuka, G. I. (2018). Food analysis and instrumentation: Theory and practice. $2^{\text {nd }}$ Edn, Napthall. Prints. Surulere Lagos- Nigeri. 140-160.

[23] James, C. S. (1995). Analytical chemistry of food. Chapman and Hall, London. Journal Research in National Developmen. 7 (1), 64-65.

[24] Mullan, W. M A. (2006). Labeling determination of the energy content of food (On-line). http://www.dairyscience.info/packing-/119-labellingdetermination-of-the-energy-content-of-food-html.

[25] Tosh, S. M. and Yada, S. (2010). Dietary fiber in pulse seeds and functions. Characterization, functional attributes and applications. Food Research International 43 (2): 450-460.

[26] Iwe, M. O. (2010). Principles of complementary foods formulation. An invited paper presented at the zonal consultation on breast feeding and complementary feeding held at the Marble Arch Hotel, Awka Anambra State.

[27] Iwe, M. O (2007). Current trends in sensory evaluation of foods. Rejoint Communication Services, Enugu, Nigeria.

[28] Mărton, M., Măndoki, Zs. Csapŏ-Kiss, Zs and Caspŏ, J. (2010). The role of sprouts in nutrition. A review. Acta Univ. Sapientiae, Alimentaria 3, 95.

[29] Igyor, M. A., Yusuf, P. A. and Sengev, I. A. (2011). Functional and sensory properties of fermented furapowder supplemented with soy powder. Nigeria Food Journal 29, 113-121.

[30] Wikipedia (2019). Amylose http://en.wikipedia.org/wiki/Amylose.

[31] Okwunodulu, I. N., Uluocha, D. M., F. U. Okwunodulu, F. U. and Ukom, A. N. (2018). Calorific value and consumers' subjective knowledge of complementary puddings from two cocoyam varieties blended with pipe plantain and sprouted soybean pastes. African Journal of Agriculture and Food Science 1 (1), 68-81.

[32] Byid-Bredbenner, C., Moe, G., Beshgtoor, D. and Berning, J. (2013). Wardlaw's Perspectives in nutrition. $9^{\text {th }}$ Edition.

\section{McGraw-Hill, New York.}

[33] Natural Food Hub [NFH] (2001). Natural Food--Fruit Vitamin $\mathrm{C} \quad$ content http://www.naturalhub.com/natural_food_guide_fruit_vitamin _c.htm.

[34] Uwaegbute, A. C. (2008). Adequate infant feeding: bed rock for national development, poverty alleviation and empowerment. Sixth Inaugural Lecture at Michael Okpara University of Agriculture Umudike 1-47.

[35] Khetarpaul, N. and Goyal, R. (2004). Nutritional and sensory evaluation of nutritious porridge prepared using combinations of soy and sorghum grits. Nutrition and Health 17 (4), 309315 .

[36] FAO/WHO, (1998). Preparation and use of food-based dietary guidelines. Report of a Joint FAO/WHO Consultation. WHO Technical Report series 880. Geneva 15.

[37] Osuji, C. M. and Ubbaonu, C. N. (2004). Chemical and physical properties of predigested soymilk concentrates developed by enzyme hydrolysis of Soybean extracts. Nutrition Society of Nigeria $34^{\text {th }}$ Annual Conference and Scientific Meeting. Theme: Child Survival and the Right of Adequate Nutrition. 2004. 116-119. York San Francisco London. 219-246.

[38] Saldanha, L. G. (1995). Fiber in the diet of U. S. Children. Results of national surveys. Pediatrics 96, 994-996.

[39] SFGATE, (2017). Normal fiber intake for children. Healthyeating.sfgate.com/normal-fiberintake-children-4548html.

[40] Niba, L. L. (2003). Processing effects on susceptibility of starch to digestion in some dietary starch sources, Int. J. Food Sci. Nutr. 54, 97-109.

[41] Slavin, J. L. (2005). Dietary fiber and body weight. Nutrition, 21, 411-418.

[42] Elleuch, M., Bedigian, D., Roiseux, O., Besbes, S., C. Blecker, C. and Attia, H. (2011). Dietary fiber and fiber-rich byproducts of food processing characterization, technological functionality and commercial applications: Rev. Food Chemistry, 124, 411-421.

[43] Penas, M, Salvia Trojillo, L, m. Alajendra, Rojas - Graur and Martin Belloso, (2008). Isoflavone profile of high intensity paulsed electric field of thermally treated fruit juice and soymilk beverage stored under refrigeration. Innovative Food Science and Emerging Technologies. 11 (4): 604-610.

[44] Okwunodulu, I. N. and Ukeje, S. C. (2018). Influence of sprouting on proximate and sensory properties of gworo (Cola nitida) and ojigbo (Cola acuminata) kola nuts Sustainable Food Production-16ISSN: 2624-876X, 2, 29-36.

[45] Oluwaseun, P. B., Mofoluwaso, B. F., Dolapo, A. O. and Ebunoluwa, G. A. (2015). Nutritional composition of fufu analog flour produced from cassava root (Manihot exculenta) and cocoyam (Colocasia esculenta) tubers. Food Science and Nutrition, 3 (6), 597-603.

[46] Badejo, A. A., Osunlakin, A. A., Pamakinwa, A. P., Idowu, A. O. and Fagbemi, T. M. (2017). Analysis of dietary fiber content, A antioxidant composition, functional and pasting properties of Plantain and moringa oleofera composite flour blends Cogat. Food and Agriculture 3, 1-10. 
[47] Okoye, J. I., Nkwocha, A. C. and Ogbonnaya, E. A. (2007). Functional and sensory properties of cornstarch/soybean flour blends. International J. Food and Agric. Res., 4 (2) 263-270.

[48] Onimawo, A. I. and Egbekan (1998). Comprehensive Food Science and Nutrition. Ambik Press Ltd Benin City. Edo State, 200-208.

[49] Boye, I. Joyce, F. Zubair, (2011). Water holding capacity: In Pulse foods. http://www.sciencedirect.com/topic/agricultural and biological-sciences/water-binding/pdf.

[50] Torruco-Uco and Brtancer-Ancona, (2011). Cited in: Water holding capacity: Pulse foods. http://www.sciencedirect.com/topic/agricultural and biological-sciences/water-binding/pdf.

[51] Fagbemi, E. N. (1999). Effects of blanching and ripening on the functional properties of plantain (Mosaaab) flour. Plant Food Human Nutrition, 54 (3), 261-269.

[52] Science of Cooking, (2018). What if fiber? http://www.science of cooking.com/what-is-flavourhtm.

[53] Oluwole, A. O. (2009). Quality control for the food industry, a statistical approach. Concept Publications Ltd. Lagos, Nigeria. 229-235. 